\title{
AIR QUALITY SURVEY \\ AT SELECTED SITES \\ ON THE HANFORD PROJECT
}

G. J. Alkire and C. R. Wyss

NOVEMBER 1967

\section{AEC RESEARCH \& DEVELOPMENT REPORT}




\section{LEGAL NOTICE}

This report was prepared as on acsount of Government sponsored work. Neither the United States. nor the Commisston, nar any person acting on behalf of the Commissions:

A. Makes any worranty or representation, expressed or implied, with respect to the accuracy, com. plefeness, or usefulness of the information contained in this report, or that the use of any information, apporatus, method, or process diselosed in this repart may not infringe privately owned rights; or

B. Assumes any liabilities with respect to the use of, or for damages resulting from the use of any information, apporatus, method, on process disclosed in this report.

As used in the above, "person acting on behalf of the Commission" includes ony employee of contractor of the Commission, or einployee of such contractor, to the extent that such employee or con. tractor of the Commission, or employee of such contractor prepares, disseminates, or provides access to, any information pursuant to his employment or contract with the Commission, of his employment with such contractor.

\section{PACIFIC NORTHWEST LABORATORY}

EICHLAND, WASHINGTON

operated by

BATIELLE MEMORIAL INSTIUUTE

for the

UNITED STATES ATOMIC ENERGY COMMISSION UNDER CONTRACT AT(45-1)-1830 


\title{
AIR QUALITY SURVEY AT SELECTED SITES ON THE HANFORD PROJECT
}

\section{By}

\author{
G. J.A1kire and C. R. Wyss \\ - Environmental and Radiological \\ Sciences Department
}

November 1967

\footnotetext{
PACIFIC NORTHWEST LABORATORY RI CHLAND, WASHINGTON
} 
Printed in the United States of America Available from

Clearinghouse for Federal Scientific and Technical information National Bureau of Standards, U.S. Department of Commerce Springfield, Virginia 22151

Price: Printed Copy $\$ 3.00 ;$ Microfiche $\$ 0.65$ 


\section{TABLE OF CONTENTS}

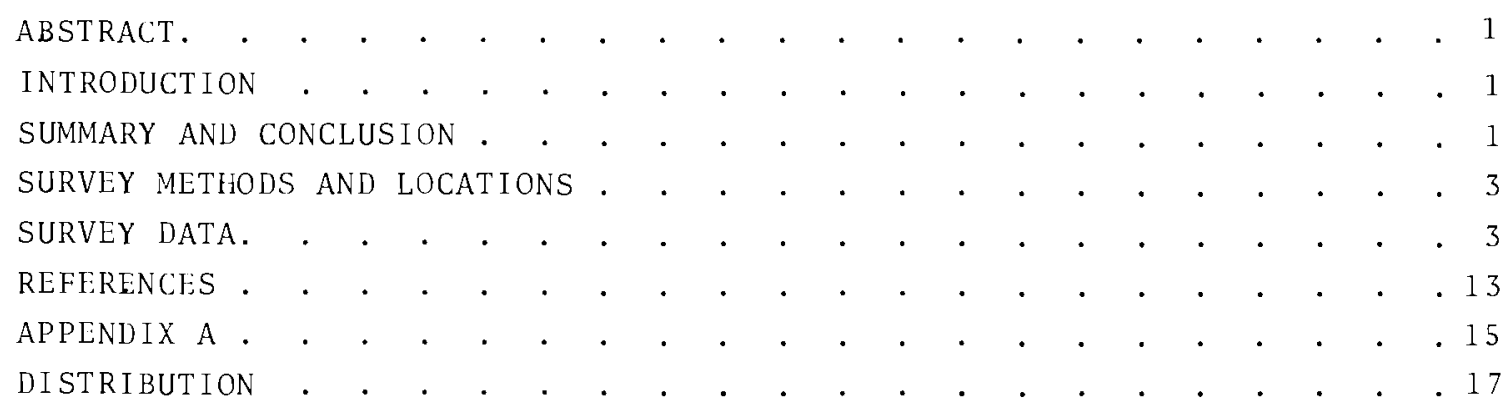

\section{LIST OF FIGURES}

1 Location of Monitoring Sites on the Hanford Project 2

2 View of Mobile Monitoring Station Looking $N$ from SE of 200 E Site 4

3 View of Mobile Monitoring Station Looking NW from SE of 200 E Site 5

$4 \quad \mathrm{NO}, \mathrm{NO}_{2}$ Analyzers and Readout Instrumentation 6

$5 \quad \mathrm{SO}_{2}$ and HCHO Analyzers 7

6 Nitrogen Oxides $\left(\mathrm{NO}+\mathrm{NO}_{2}\right) 15006 / 29 / 67--04006 / 30 / 67$ at $\mathrm{SE}$ of 200 E Site

7 Diurnal Variation $\mathrm{NO}_{2}$ at $\mathrm{SE}$ of 200 E Site; Average for a 20 Day Period

\section{$\underline{\text { LIST OF TABLES }}$}

I Detection Limits, Concentration Range and Column Efficiencies 8

I I Summary Data All Sites 9

II Hourly Averages Nitrogen Dioxide 11

IV Hourly Averages Nitric Oxide plus Nitrogen Dioxide 11

V Hourly Averages Sulfur Dioxide $\quad 12$

VI Wind Direction and Average Speed (SE of 200 E 6/23-7/14) 
AIR QUALITY SURVEY AT SELECTED SITES ON THE HANFORD PROJECT

G. J. Alkire and C. R. Wyss

\begin{abstract}
The concentration of five potentially significant air pollutants ( $\mathrm{SO}_{2}$, $\mathrm{NO}, \mathrm{NO}_{2}, \mathrm{HCHO}$, and $\mathrm{H}_{2} \mathrm{Sl}$ was measured at selected sites on the Hanford Project during the period May 17, 1967, through July 14, 1967. The observed concentration of these gases was below the detection limit most of the time, but significant levels of nitrogen oxides and sulfur dioxide were observed at some sites part of the time. Downwind of a chemical separations plant, nitrogen oxides (NO + NO2 ) were above detection limits $(0.01 \mathrm{ppm})$ about $30 \%$ of the time. Peak NO + NO2 concentrations ranged to $0.36 \mathrm{ppm}$, and hourly averages ranged to $0.12 \mathrm{ppm}$. Average sulfur dioxide concentrations were less than or equal to background $96 \%$ of the time at two sites, and $89 \%$ of the time at a third site. Aldehydes and hydrogen sulfide were not detected above background during the survey.
\end{abstract}

\section{INTRODUCTION}

A 1 imited air-quality survey was conducted at four sites on the Hanford Project to measure, in ambient air, the concentrations of gaseous sulfur dioxide $\left(\mathrm{SO}_{2}\right)$, nitric oxide (NO), nitrogen dioxide $\left(\mathrm{NO}_{2}\right)$, aldehydes as formaldehyde (HCHO), and hydrogen sulfide $\left(\mathrm{H}_{2} \mathrm{~S}\right)$. These gaseous compounds are representative of potentially significant air pollutants which arise from coal burning $\left(\mathrm{SO}_{2}\right)$, industrial processes $\left(\mathrm{NO}+\mathrm{NO}_{2}\right)$, a secondary product from auto exhaust emissions ( $\mathrm{HCHO}$ ), and a possible local air pollutant $\left(\mathrm{H}_{2} \mathrm{~S}\right)$. The sites selected for continuous monitoring represent a laboratoryprocessing area (300 Area), a semirural area (Meteorology Tower), a steam power plant and reactor area $(100 \mathrm{D})$, and a chemical processing area (SE of 200E). The locations of the sampling sites are shown in Figure 1. Previous studies on emissions from Redox and Purex include an evaluation of the oxides of nitrogen in the environs of the plant stacks, (1) and an evaluation of meteorological factors in appraisal and control of exposures. (2)

\section{SUMMARY AND CONCLUSION}

An air-quality survey was conducted on the Hanford Project to assess the present burden of five gaseous chemicals that are potentially significant air pollutants. Air was sampled at the 325 Building, 300 Area; and at a trailer-based station which was located successively at the meteorological tower (near $200 \mathrm{~W}$ ), at $100 \mathrm{D}$, and about 1 mile SE of Purex. Analyses were made continuously for sulfur dioxide, nitric oxide, nitrogen dioxide, aldehydes as formaldehyde, and hydrogen sulfide. 


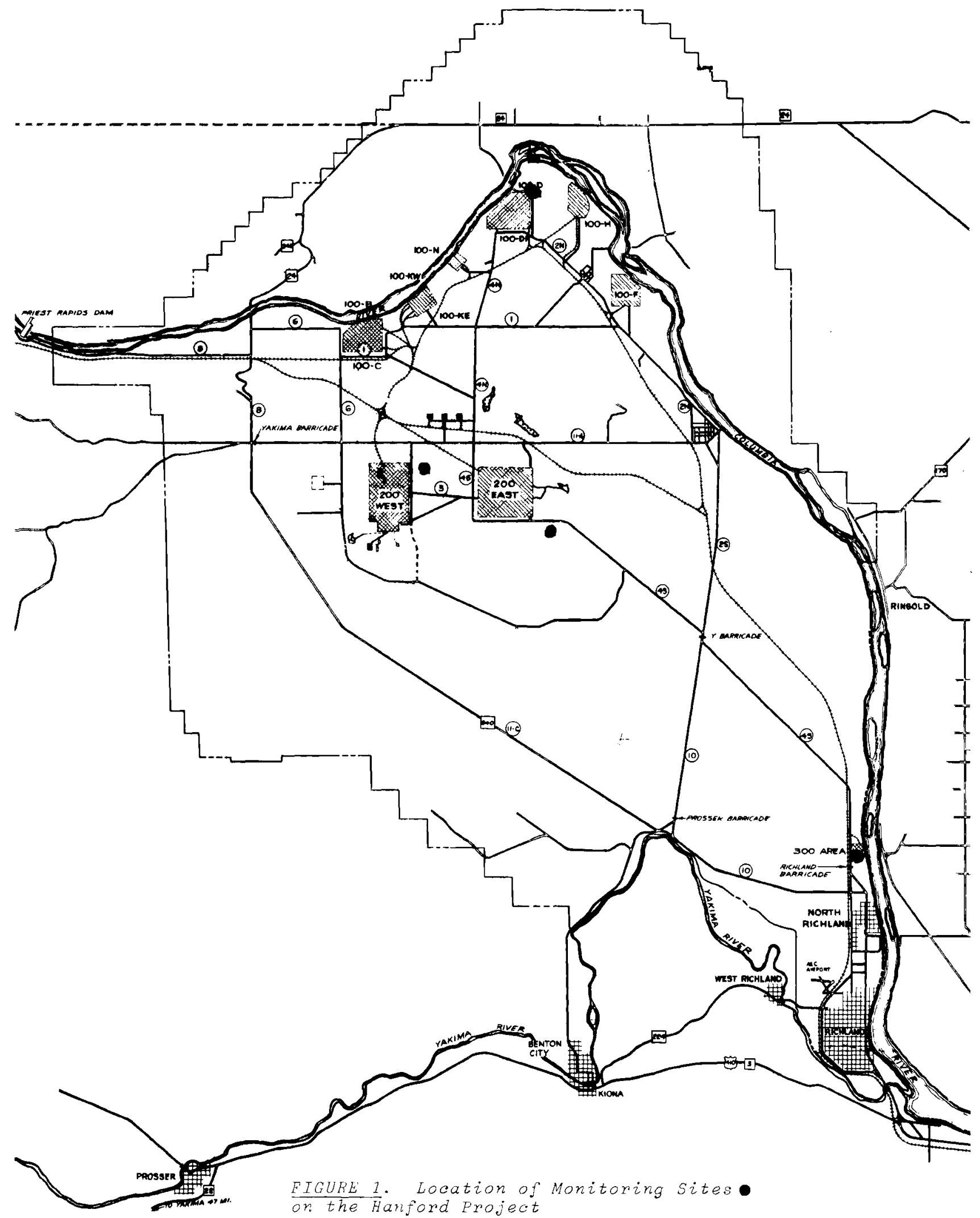


General conclusions from the results of the survey are:

- Most of the time during the survey, the ambient air at all four sampling sites contained insignificant levels of the constituents measured.

- The levels of sulfur dioxide are considerably less than those reported by most large urban areas. (3)

- The peak $\mathrm{NO}-\mathrm{NO}_{2}$ concentrations sampled near the chemical separations plants are significantly above the general background level for $\mathrm{NO}-\mathrm{NO}_{2}$, yet considerably less than the values reported earlier. (1)

- Aldehydes and $\mathrm{H}_{2} \mathrm{~S}$ concentrations were less than the detection limits of the method used.

- Simultaneous and continuous monitoring over an extended time period at several locations is necessary to obtain more definitive synoptic information on the ambient air quality.

\section{SURVEY METHODS AND LOCATIONS}

Sulfur dioxide and aldehydes were determined colorimetrically by the method of West and Gaeke. (4) Nitrogen dioxide and nitric oxide-after oxidation to nitrogen dioxide-were determined colorimetrically by use of the Griess reaction as adapted by Saltzman. $(5,6,7)$ Hydrogen sulfide was monitored with the well known AISI tape sampler. In the colorimetric methods, air and aqueous absorbing reagents flowed concurrently through columns packed with glass beads. The air-1iquid mixture was then separated. Additional reagents were added if necessary for proper color development. The 1ight absorbance of the aqueous phase was then measured at a preselected wave length and recorded versus time. In the tape sampler, air was drawn through paper tape impregnated with lead acetate, and the sulfide concentration was determined by measuring the light absorbance of the exposed tape.

The continuous analyzers* (Technicon Autoanalyzers $(\mathbb{R})$ were installed in a 15 foot house trailer that functioned as a monitoring station near the main meterology tower, at the NE corner of $100 \mathrm{D}$ area, and at the old army camp about one mile SE of the Purex Plant. Air was continuously sampled at points about two feet above the trailer roof, and drawn by vacuum (via polyethylene and glass tubing) into the absorption columns. Wind speed and direction were measured at the SE of 200 E site with an anemometer and wind vane. The temperature and relative humidity inside the trailer was also measured at this site. Two views of the trailer exterior are shown in Figures 2 and 3 , and two views of the analyzers as installed in the trailer are shown in Figures 4 and 5 .

The nitrogen oxides and hydrogen sulfide analyzers were operated in the penthouse on the roof of the $325^{\circ}$ Building, 300 Area. Air was sampled at about the three foot level on the outside of the penthouse.

\section{SURVEY DATA}

The data obtained in this survey are presented in Tables I through VI. Detection limits, instrument range, and absorption column efficiencies are

* Battelze-Northwest instrumentation for use in support of environmental research programs. 


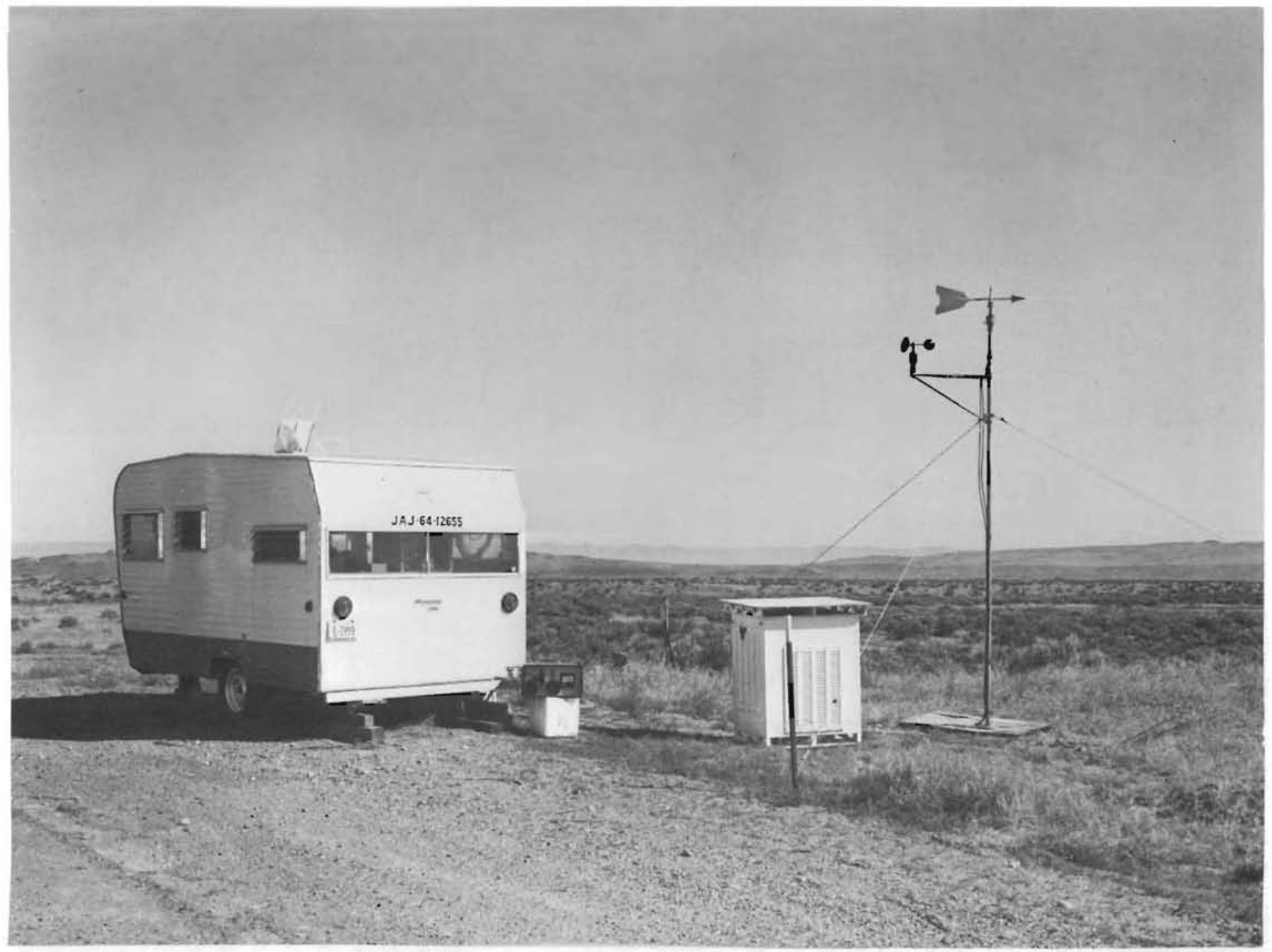

FIGURE 2. View of Mobile Monitoring

Station Looking N from SE of $200 \mathrm{E}$ 


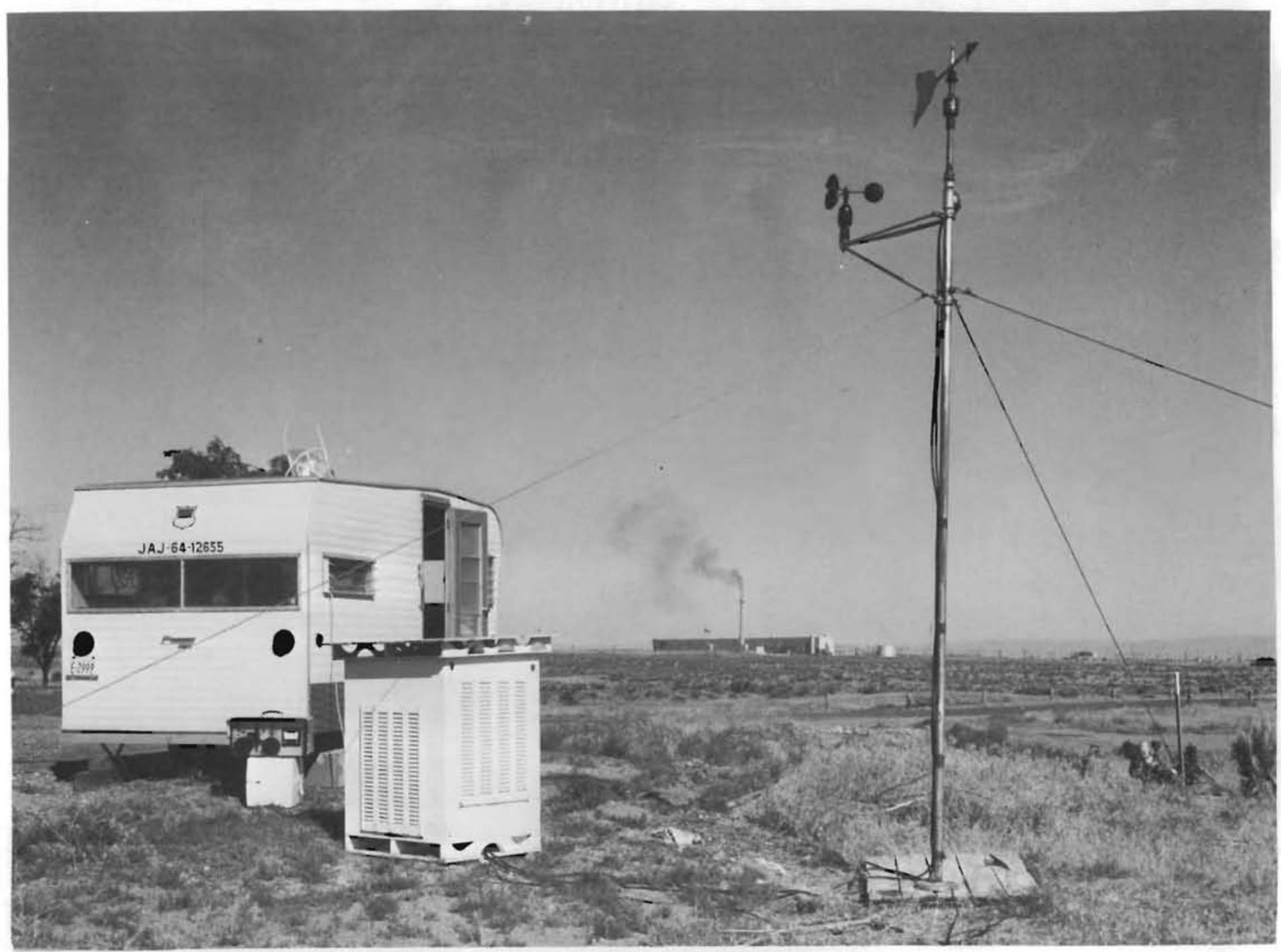

u

FIGURE 3, View of Mobile Monitoring Station Looking NW from SE of $200 \mathrm{E}$ 


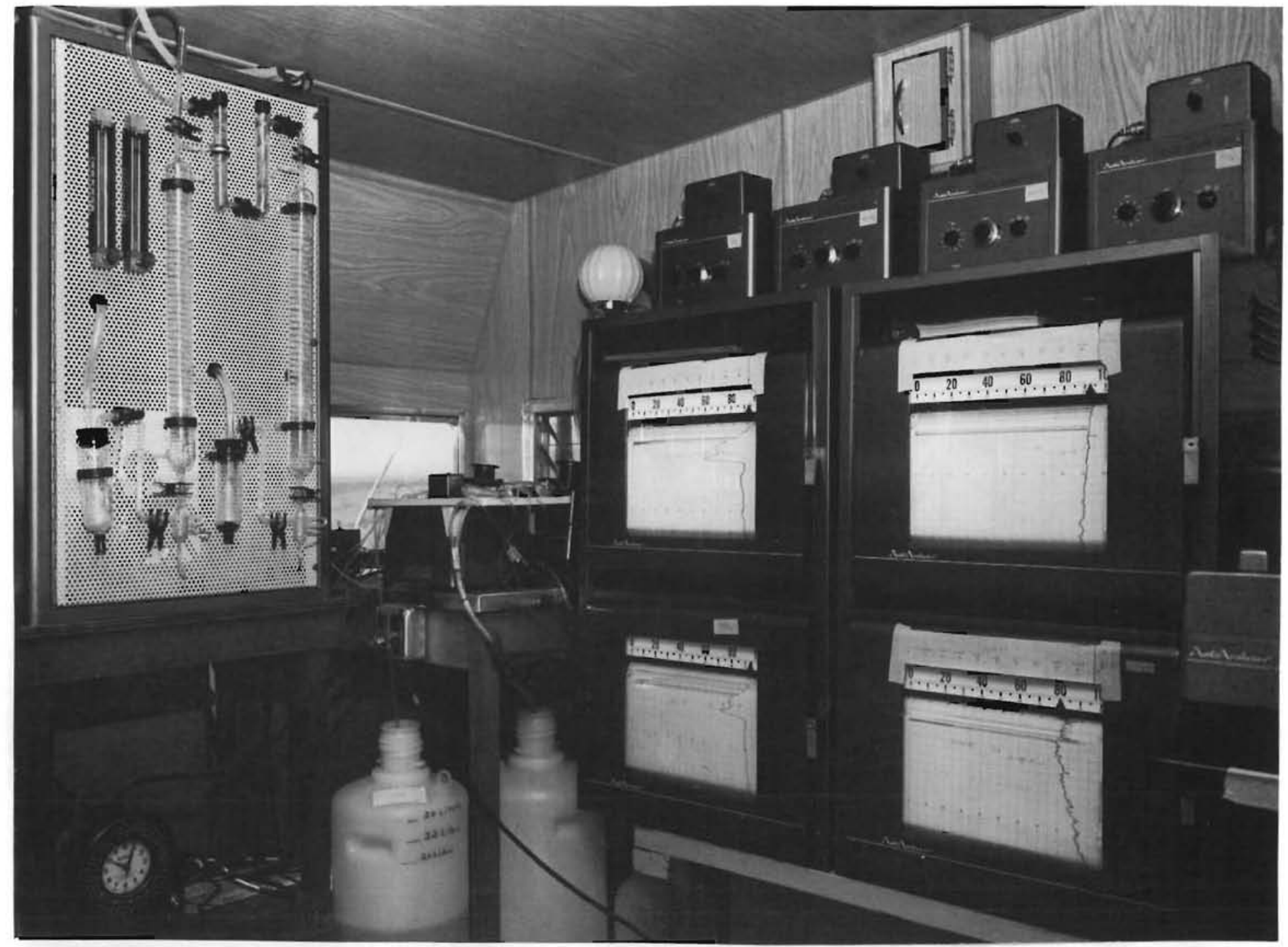

FIGURE 4. NO, NO, Analyzers and Read- 


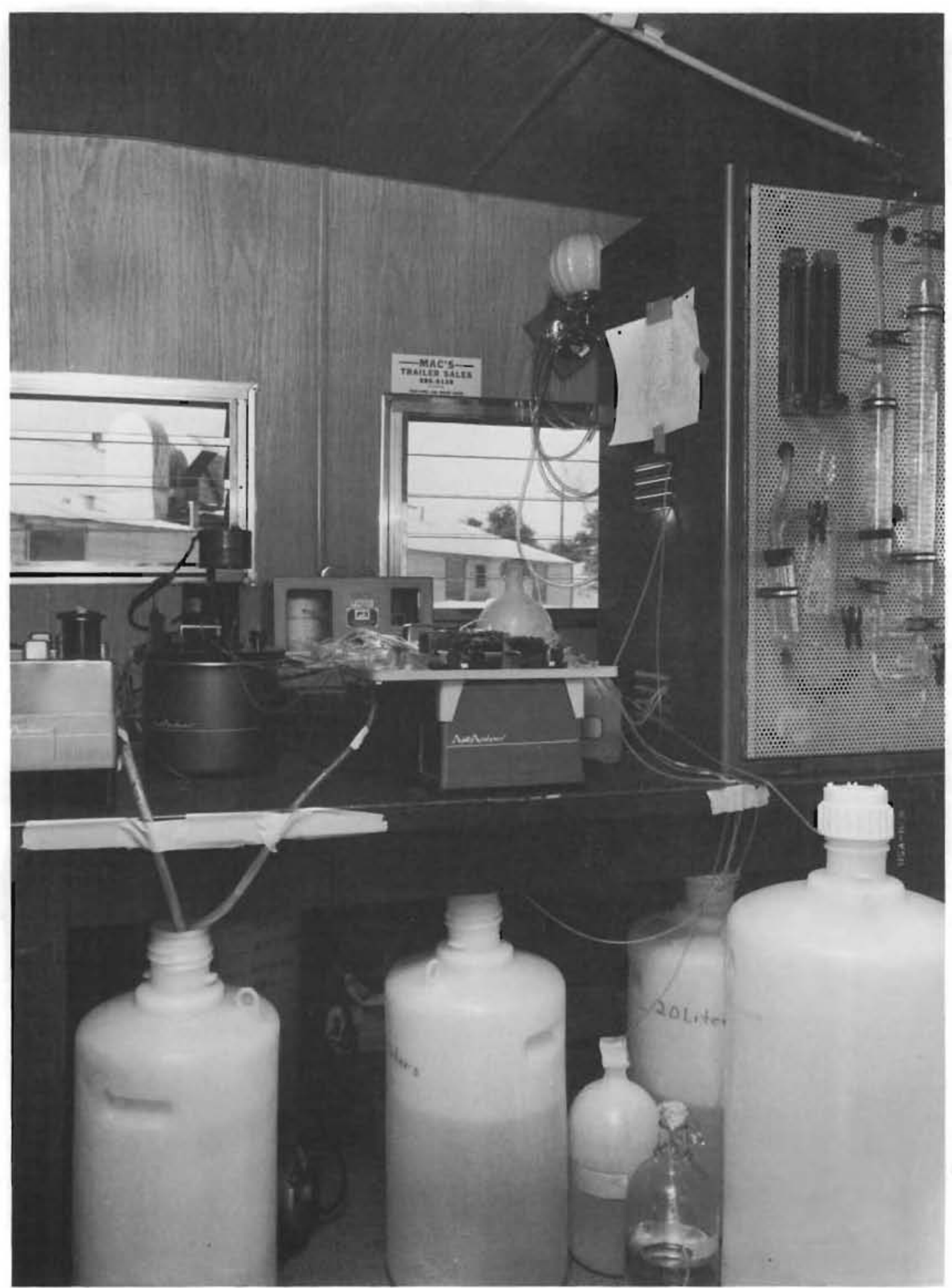


shown in Table I. The aldehyde and hydrogen sulfide analyzers were operated most of the time during the survey, however these gases were not positively detected at any time. The most reliable data obtained during the survey were collected at the SE 200 of E site. This is because most of the minor operational problems were resolved at the earlier sites; more hours of valid data were gathered; automatic base line fecording for $\mathrm{NO}$ and $\mathrm{NO}_{2}$ was initiated; and wind speed and direction were measured. A strip chart record of $\mathrm{NO}+$ $\mathrm{NO}_{2}$ values versus time as recorded on June 29-30, 1967, is shown in Figure 6 to illustrate the type of output data obtained with the analyzers. The variables on the scan are light absorbance at $550 \mathrm{~m} \mu$ versus time.

A summary of the data obtained at the four sites is presented in Table II. These data show that the concentrations of the gases measured at the sampling sites are generally very low and that the significant concentrations measured are from local emissions. The concentrations 1 isted in Tables II through $\mathrm{V}$ are given in parts per hundred million (pphm), a unit commonly used for expressing concentrations of gaseous air pollutants.

The data presented in Tables III, $I V$ and $V$ are hourly averages based on instantaneous values recorded by the instrument at $15 \mathrm{~min}$ intervals. Values isted that are less than the detection limit are measurable values above background, but are considered only semi-quantitative and are shown primarily for comparative purposes. Values shown as "less than" (<) indicate no measurable value above background. Arrows between "less than" values indicate "less than" for the period shown. The values 1 isted as highest concentration are peak values recorded by the instrument. These peaks are integrated values and, therefore, are not as meaningful as the hour1y averages. Wind speed and direction measured at the SE of $200 \mathrm{E}$ site are listed in Table VI. Comparison of these data with those in Tables III and IV shows that winds were generally West to Northwest when significant $\mathrm{NO}_{2}$

\begin{tabular}{|c|c|c|c|}
\hline Substance & $\begin{array}{c}\text { Positive Detection } \\
\text { Limit, } \mathrm{ppm} \\
\end{array}$ & $\begin{array}{l}\text { Nominal } \\
\text { Range XI, } \\
\text { ppm }\end{array}$ & $\begin{array}{c}\text { Absorption Column } \\
\text { Efficiency }\end{array}$ \\
\hline $\mathrm{NO}_{2}$ & 0.010 & $0-0.30$ & 0.95 \\
\hline NO & 0.010 & $0-0.30$ & 0.95 \\
\hline $\mathrm{SO}_{2}$ & 0.015 & $0-1.10$ & $0.98^{(8)}$ \\
\hline $\mathrm{HCHO}$ & 0.025 & $0-0.60$ & $0.96^{(8)}$ \\
\hline $\mathrm{H}_{2} \mathrm{~S}$ & $0.010 *$ & $0-0.15$ & --- \\
\hline
\end{tabular}

Manufactures stated limit and range 


$$
\text { Did] }
$$


TABLE II. Summary Data AlZ Sites

\begin{tabular}{|c|c|c|c|c|c|}
\hline $\begin{array}{l}\text { Date, Location and } \\
\text { Chemical Analyzed }\end{array}$ & $\begin{array}{l}\text { No. of Hours of } \\
\text { Valid Data } \\
\end{array}$ & $\begin{array}{l}\text { No. of Hourly Averages } \\
\text { Greater Than } 1 \text { pphm } \\
\end{array}$ & $\begin{array}{r}\text { Percentage of Time } \\
\text { Greater Than } 1 \mathrm{pphm}\end{array}$ & $\begin{array}{l}\text { Highest Hourly } \\
\text { Average, } \mathrm{pphm}\end{array}$ & $\begin{array}{c}\text { Highest } \\
\text { Concentration, pphm }\end{array}$ \\
\hline \multicolumn{6}{|l|}{$5 / 15-5 / 22 \quad(300$ Area $)$} \\
\hline $\begin{array}{r}\mathrm{NO}_{2} \\
\mathrm{NO}^{2} \\
\mathrm{SO} \\
\mathrm{HCHO} \\
\mathrm{H}_{2} \mathrm{~S}\end{array}$ & $\begin{array}{r}109 \\
52 \\
0 \\
0 \\
68\end{array}$ & $\begin{array}{r}12 \\
8\end{array}$ & $\begin{array}{l}11 \\
15\end{array}$ & $\begin{array}{r}3.0 \\
2.0 \\
\\
<1.0\end{array}$ & $\begin{aligned} & 4.0 \\
& 3.0 \\
< & 1.0\end{aligned}$ \\
\hline \multicolumn{6}{|c|}{$6 / 5-6 / 12$ (Meterology Tower) } \\
\hline $\begin{array}{c}\mathrm{NO}_{2} \\
\mathrm{NO}^{2} \\
\mathrm{SO}_{2} \\
\mathrm{HCHO} \\
\mathrm{H}_{2} \mathrm{~S}\end{array}$ & $\begin{array}{l}141 \\
150 \\
131 \\
152 \\
172\end{array}$ & $\begin{array}{l}0 \\
0 \\
0 \\
0 \\
0\end{array}$ & $\begin{array}{l}0 \\
0 \\
0 \\
0 \\
0\end{array}$ & $\begin{array}{l}<1.0 \\
<1.0 \\
<1.0 \\
<2.0 \\
<1.0\end{array}$ & $\begin{array}{l}<1.0 \\
<1.0 \\
<1.0 \\
<2.0 \\
<1.0\end{array}$ \\
\hline \multicolumn{6}{|l|}{$\underline{6 / 14-6 / 21(100 \quad D})$} \\
\hline $\begin{array}{c}\mathrm{NO}_{2} \\
\mathrm{NO}_{2} \\
\mathrm{SO} \\
\mathrm{HCHO} \\
\mathrm{H}_{2} \mathrm{~S}\end{array}$ & $\begin{array}{l}143 \\
145 \\
112 \\
143 \\
132\end{array}$ & $\begin{array}{r}0 \\
0 \\
13 \\
0 \\
0\end{array}$ & $\begin{array}{r}0 \\
0 \\
11 \\
0 \\
0\end{array}$ & $\begin{aligned}<1.0 \\
<1.0 \\
3.0 \\
<2.0 \\
<1.0\end{aligned}$ & $\begin{array}{l}<1.0 \\
<1.0 \\
10.0 \\
<2.0 \\
<1.0\end{array}$ \\
\hline \multicolumn{6}{|c|}{$6 / 23-7 / 14($ SE of $200 E)$} \\
\hline $\begin{array}{c}\mathrm{NO}_{2} \\
\mathrm{NO}^{2} \\
\mathrm{SO}_{2} \\
\mathrm{HCHO}_{2} \\
\mathrm{H}_{2} \mathrm{~S}\end{array}$ & $\begin{array}{l}374 \\
226 \\
450 \\
233 \\
209\end{array}$ & $\begin{array}{r}88 \\
74 \\
19 \\
0 \\
0\end{array}$ & $\begin{array}{r}24 \\
33 \\
4 \\
0 \\
0\end{array}$ & $\begin{array}{r}10.0 \\
6.0 \\
2.0 \\
<2.0 \\
<1.0\end{array}$ & $\begin{array}{r}16.0 \\
23.0 \\
9.0 \\
<2.0 \\
<1.0\end{array}$ \\
\hline
\end{tabular}


Date and
Location

(300 Area)

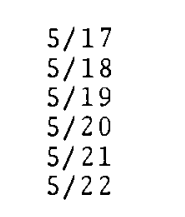

$\underline{(S E \text { of } 200 \mathrm{E})}$

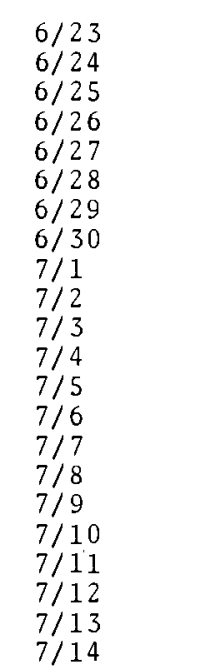

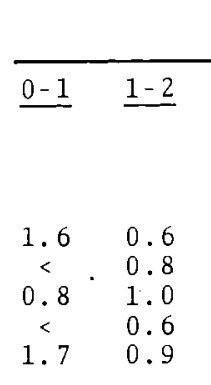
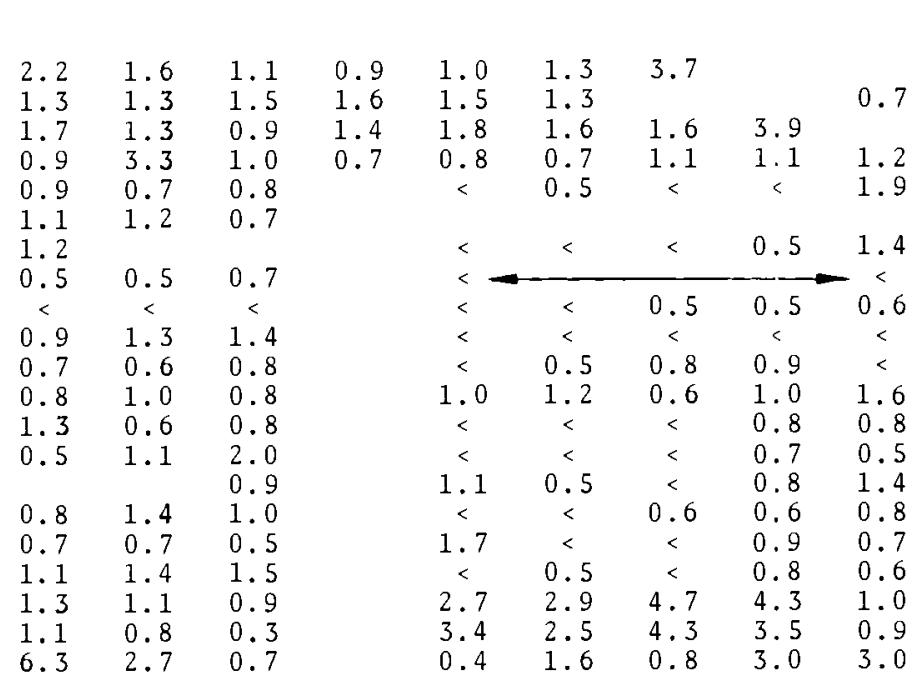

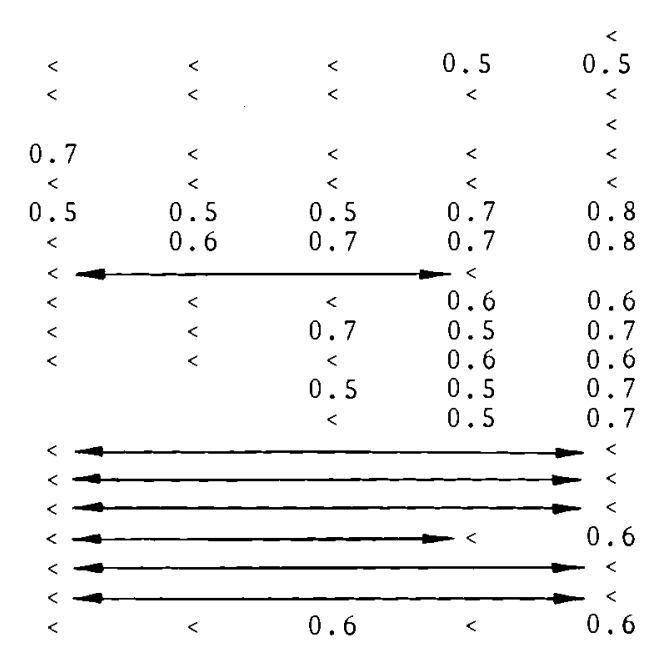

TABLE III. Hourly Averages Nitrogen Dioxide, pphm
Daily

$\frac{\text { Highest Value }}{\text { Time }}$

$\begin{array}{ll}2145 & 3.4 \\ 0200 & 1.5 \\ 01100 & 1.6 \\ 2100 & 4.4 \\ 0030 & 3.4\end{array}$

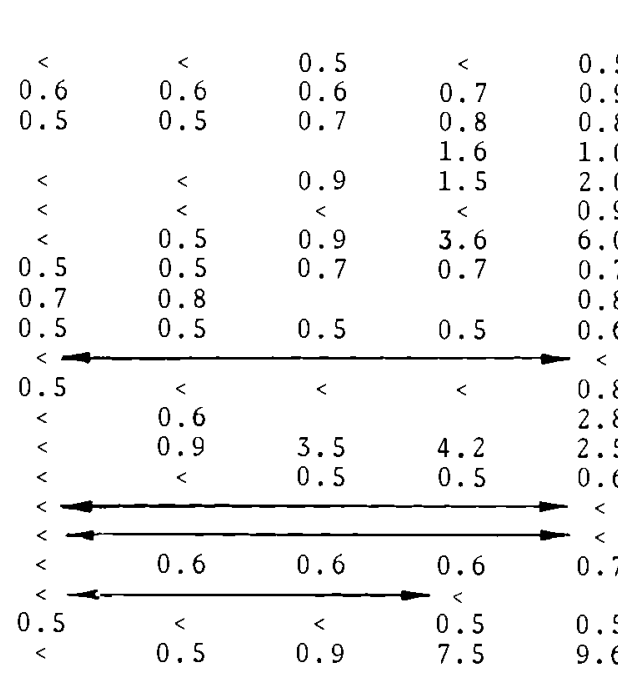

$\begin{array}{ll}0.5 & 0.9 \\ 0.7 & 0.7 \\ 0.8 & 0.8 \\ 0.7 & 0.6\end{array}$

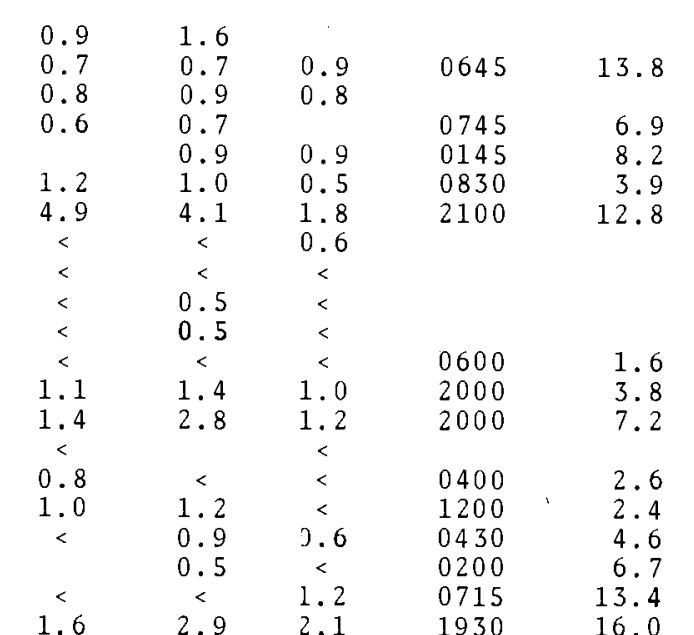

Date and
Location (300 Area) $5 / 17$
$5 / 18$
$5 / 19$

(SE of $200 \mathrm{E})$

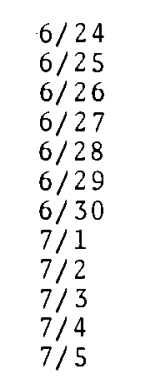

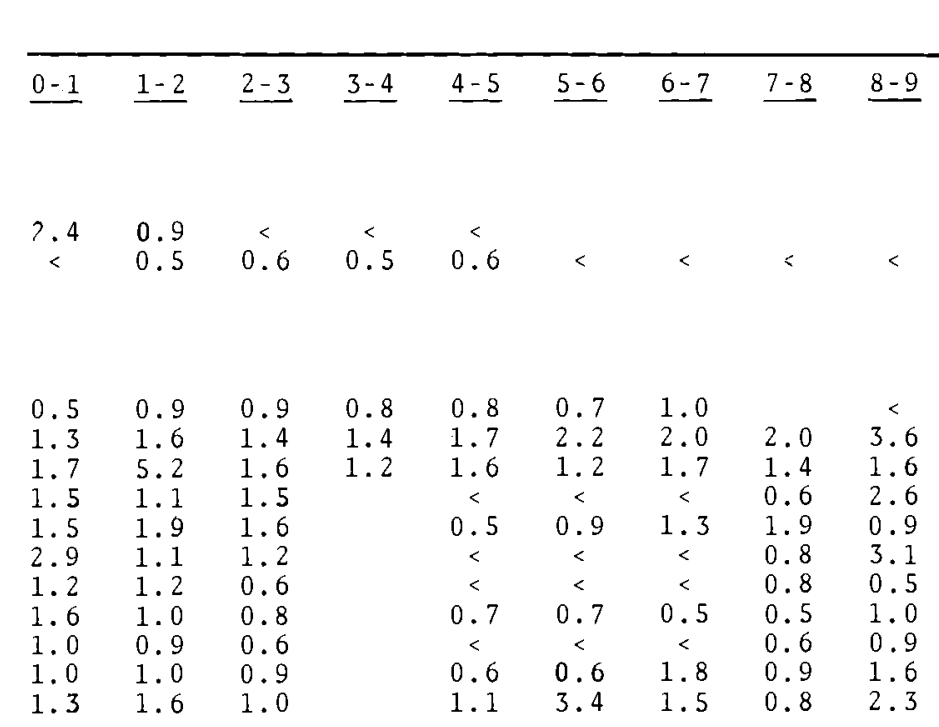

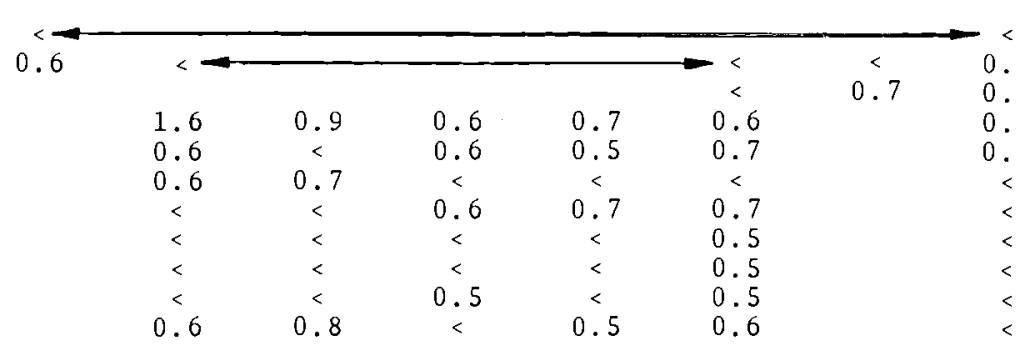

$\begin{array}{ccccc}< & < & < & < & < \\ 0.6 & 0.8 & < & 0.5 & 0.5 \\ & & & & 0.6\end{array}$
Daily
Mean Highest value
pphm $2300 \quad 6.1$ $0200 \quad 0.9$

TABLE IV. Hourly Averages Nitric oxide Plus Nitrogen Dioxide, pphm 

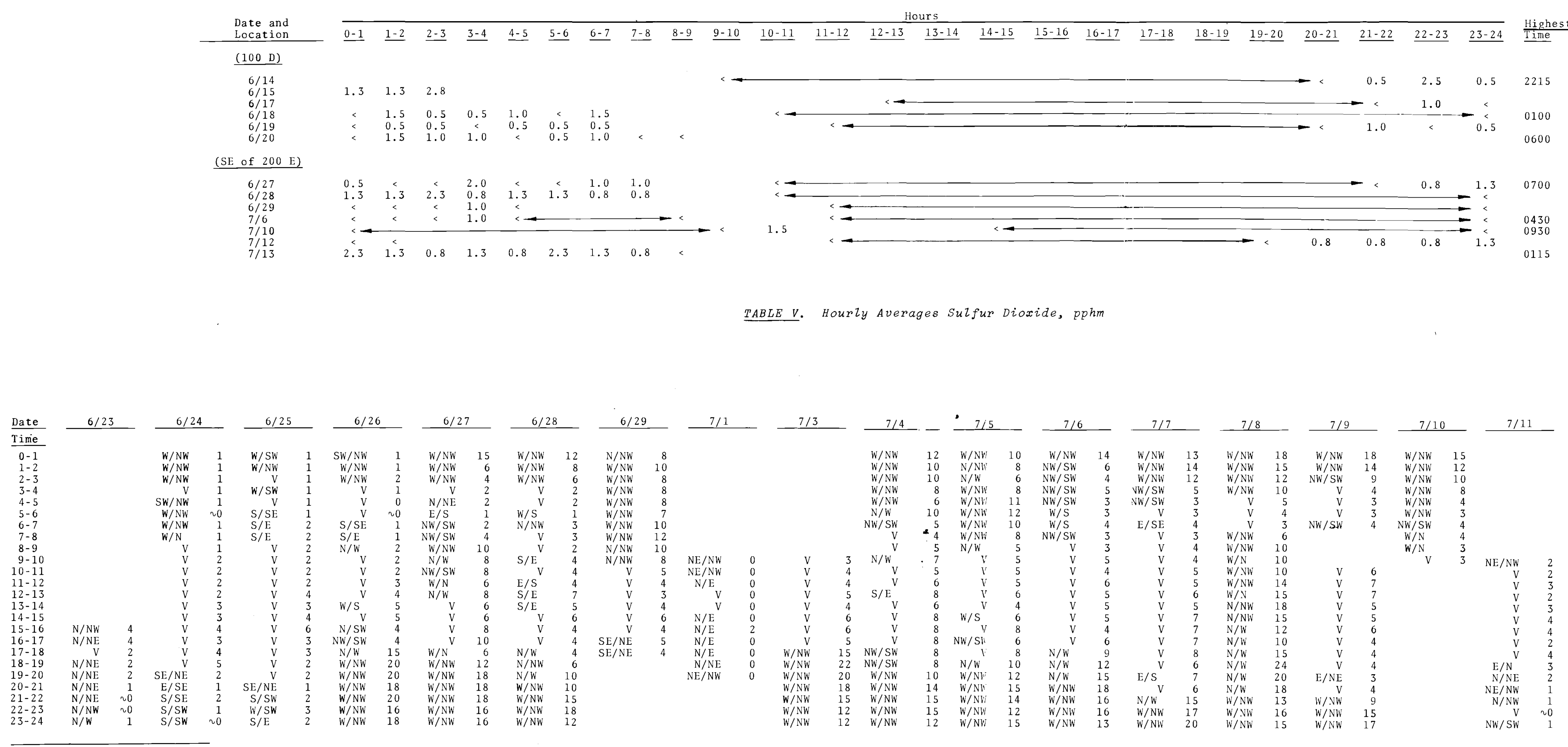


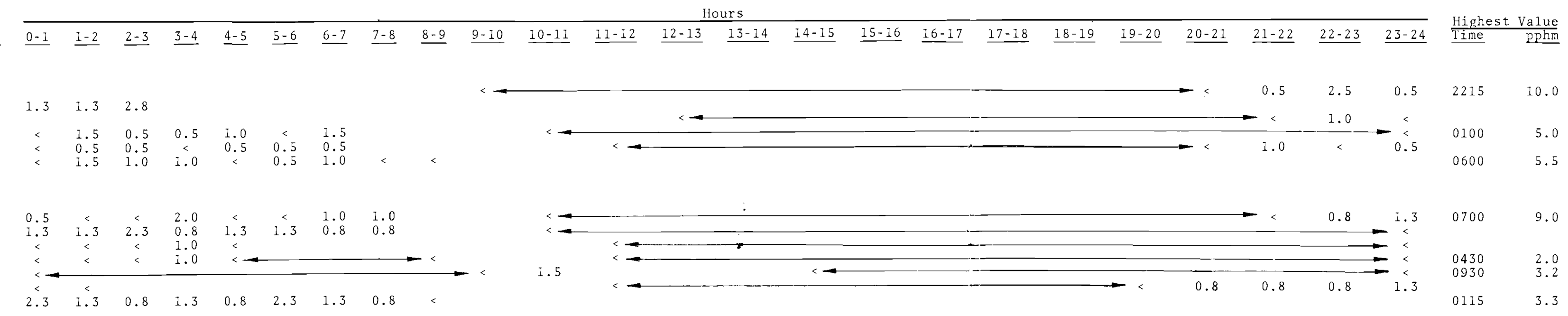

TABLE V. Hourly Averages Sulfur Dioxide, pphm

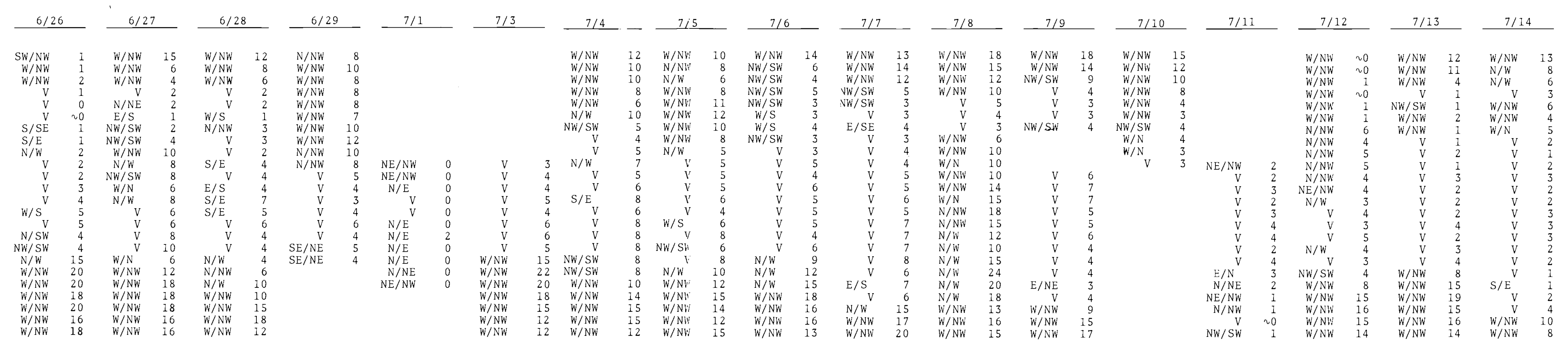


concentrations were observed. A diurnal pattern of wind direction and $\mathrm{NO}_{2}$ concentration also was observed (Figure 7).

\section{REFERENCES}

1. C. P. Skizzern. Unpublished Data. Richland, washington, 1957. (Report)

2. J. J. Fuquay. "Meteorological Factors in the Appraisal and Control of Acute Exposure to Stack Effluents," 2nd UN Geneva Conference, vol. 18, March 1958.

3. "Air Quality Data from the National Air Sampling Network," U.S. Dept. HEW - Public Health Service - Div. of Air poliution. Cincinnati, ohio, 1964-1965.
4. P. W. West and $r_{\text {. C. Caeke. }}$ Analytical Chem., vol. 28, pp. 18161819.1956.

5. B. E. Saltzman. Analytical Chem., vol. 28, pp. $1816 \overline{-1819.1956 .}$

6. B. E. Saltzman. Analytical Chem., vol. 32, pp. 135. 1960 .

7. B. E. Saltaman. Analytical Chem., vol. 36, p. 1300-1304. 1964.

8. R. S. Yunghans, W. A. Monroe, and N. J. Lewis. "Continuous Air Monitoring with the Autoanalyzer A Five Month Review of operating Experience," Technicon Symposium, oct. 19,1966 .

9. R. S. Yunghans and W. A. Monroe. "Continuous Monitoring of Ambient Atmosphere with the Technicon Autoanalyzer," Technicon Symposium, Sept. 8, 1965. 


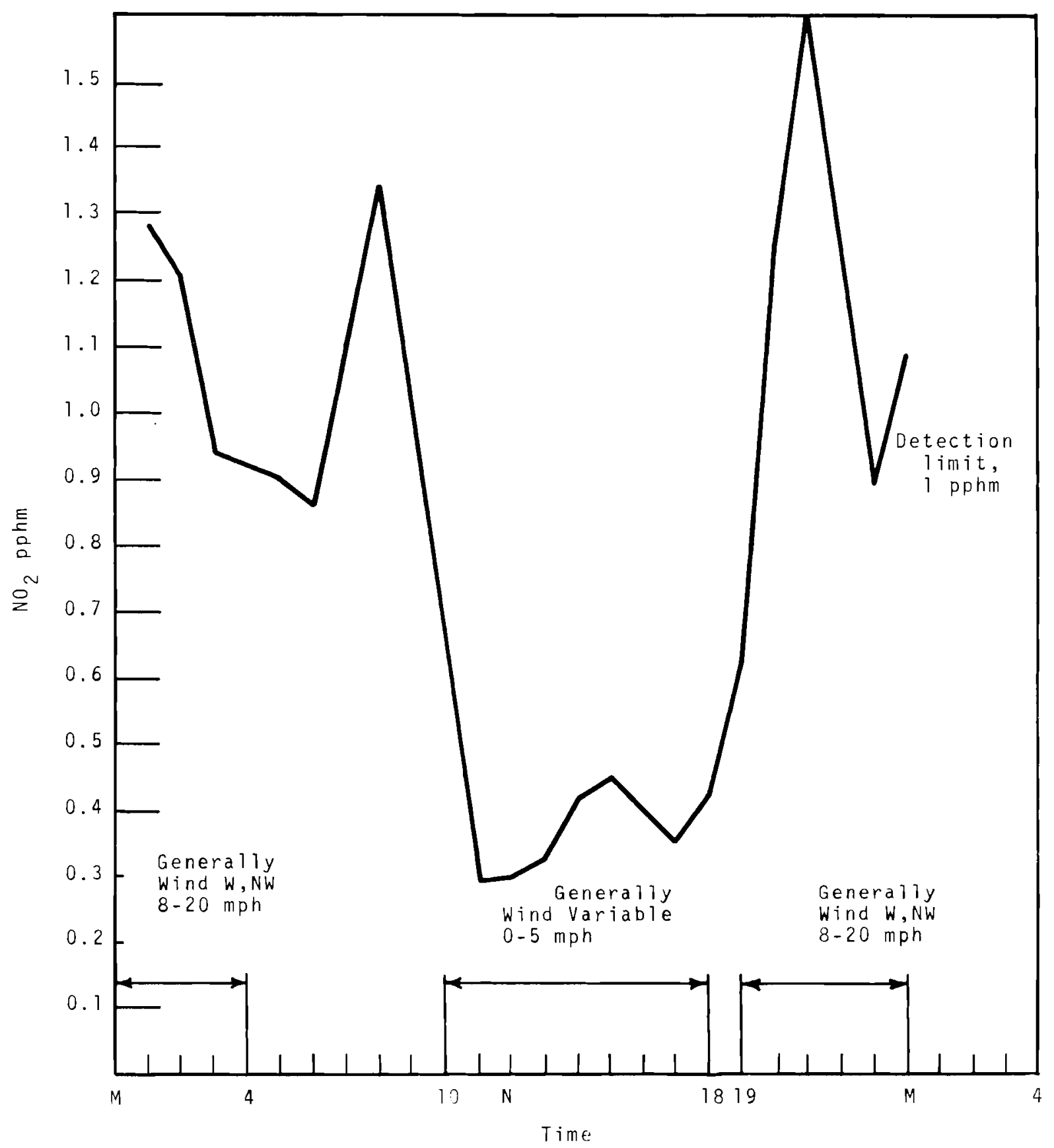

FIGURE ?
of 200 Himrnal Variation $\mathrm{NO}_{2}$ at $S E$
$; \quad \because \in$ rage for a 20 Day Period 


\section{APPENDIX A}

\section{SULFUR DIOXIDE AND FORMALDEHYDE}

Sulfur dioxide and formaldehyde are determined by use of the west and Caeke ${ }^{(9)}$ method based on the Schiff reaction:

$$
\begin{aligned}
& \mathrm{SO}_{2}+\left[\mathrm{Hg} \mathrm{Cl}{ }_{4}\right]=+\mathrm{H}_{2} \mathrm{O} \longrightarrow\left[\mathrm{Hg} \mathrm{SO} \mathrm{Cl}_{2}\right]^{=}+2 \mathrm{Cl}^{-}+2 \mathrm{H}^{+} \\
& \text {dichlorosolfitomercurate } \\
& \mathrm{HCHO}+\left[\mathrm{Hg} \mathrm{SO}_{3} \mathrm{Cl}_{2}\right]=\longrightarrow \mathrm{HOCH}_{2} \mathrm{OSO}_{2} \mathrm{H}+\mathrm{Hg} \mathrm{Cl}_{2} \\
& \mathrm{HOCH}_{2} \mathrm{OSO}_{2} \mathrm{H}+\mathrm{HN}_{2}
\end{aligned}
$$

The absorbance of red purple pararosanaline methylsulfonic acid is measured at $562 \mathrm{m \mu}$. For sulfur dioxide determinations, an excess of aldehyde is provided; for the aldehyde determination an excess of sulfite is provided. This method is not subject to interference from other acidic or basic gases or solids, hut concentration of ozone and nitrogen dioxide higher than the sulfur dioxide can cause interference.

\section{NITRIC OXIDE AND NITROGEN DIOXIDE}

Nitric oxide and nitrogen dioxide are determined by use of the Griess test as adapted by saltzman. $(5,6,7)$ The chemistry of this method is represented by the following equations.

$$
2 \mathrm{NO}_{2}+\mathrm{H}_{2} \mathrm{O} \longrightarrow \mathrm{HNO}_{2}+\mathrm{HNO}_{3}
$$
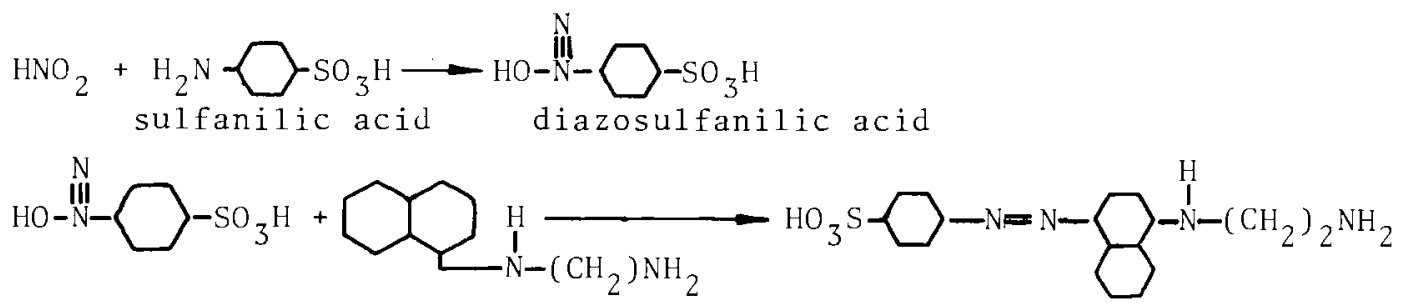

$\mathrm{N}$ - (1-naph thy 1 - e thy lenediamine $)$

The absorbance of the stable pink color produced is measured at $550 \mathrm{~m} \mu$. Nitric oxide is determined after it is converted to nitrogen dioxide by oxidation with chromium trioxide paper. Only minor interferences occur from other gases.

\section{INSTRUMENTATION}

The four colorimetric analyzers used are basically identical with the exception of the chemistry employed, and the wave length at which the light absorbance is measured. The Technicon Autoanalyzers $\mathrm{B}$ have been described in 
detail elsewhere ${ }^{(8,9)}$ and will be described only briefly here. The basic component of the analyzer system is a constant speed peristaltic pump. The flow rates and flow ratios of all reagents in the methodology are maintained by the diameter of the pump tubing. Air flow rates are measured with calibrated rotameters. Flow diagrams for the methods used are reported by Yunghans. (9)

\section{CALIBRAT I ON}

Static calibrations were made by diluting known quantities of sodium nitrite, sodium meta bisulfite, and formaldehyde with the proper absorbing solution for nitrogen oxides, sulfur dioxide, and formaldehyde, respectively. The standards used in this survey were prepared by BNW's Analytical Laboratories. Absorption efficiencies for $\mathrm{NO}_{2}$ were determined to be greater than $95 \%$. Absorption efficiencies determined by Yunghans ${ }^{(8)}$ on identical apparatus and under comparable sampling conditions were used in computing the $\mathrm{SO}_{2}$ and HCHO calibration curves from the static calibration data. The $\mathrm{NO}_{2}$ analyzers were calibrated dynamically with gas mixtures. The dynamic and static calibration data agreed within experimental error. Dynamic calibrations for $\mathrm{SO}_{2}$ are planned for confirmation, but any revisions are expected to be small, and are not expected to affect the magnitude or the trends of the data reported here.

problems encountered during the survey were primarily caused by the fluctuating and high temperatures (up to $115^{\circ} \mathrm{F}$ ) in the trailer. The analyzers per se performed exceptionally well in view of the temporary setup in the trailer. Difficulties with the recorder chart paper and pens were caused by the high temperatures. 
Number of Copies

5

AEC Division of Technica1 Information Extension

2

AEC Richland Operations

R. K. Sharp

Technical Information Library

1

Air Pollution Technical Information Center National Center for Air Pollution Control

Public Health Service, DHEW

330 C Street, SW, Rm 7042 So. Washington D.C. 20201

S. A. Tancredi, Chief

2

Atlantic Richfield Hanford Company

R. J. Sloat

File

2

Douglas United Nuclear, Inc.

R. G. Geier

File

1

Illinois Department Public Health

Air Pollution Laboratory

317 N. 2nd St

Springfield, Illinois

M. J. Rohlinger

1

New York State Department

of Health

Division of Air Resources

84 Holland Ave.

Albany, New York 12208

G. E. Blanchard

1

United States Department of Interior

Federal Water Pollution

Control Administration

Room 570 Pittock Block

Portland, Oregon 97250

1

University of Washington

Department of Civil Engr. 301 More Hal1

Seattle, Washington 98105

A. T. Rossano

Washington State Department of Health

1510 Smith Tower Seattle, Washington 98104

R. L. Stockman

Batte11e-Northwest

F. E. Adley

G. J. Alkire (50)

E. W. Christopherson

J. P. Corley

G. M. Dalen

D. R. deHalas

R. F. Foster

J. J. Fuquay

J. F. Honstead

A. R. Keene

J. M. Nielsen

R. S. Paul

L. C. Schwendiman

R. H. Scott

J. Se1by

C. L. Simpson

C. J. Touhi11

C. R. Wyss

Technical Information Files (5)

Technical Publications (2) 
